\title{
Acute Generalized Exanthematous Pustulosis: Pathogenesis, Genetic Background, Clinical Variants and Therapy
}

\author{
Laurence Feldmeyer *, Kristine Heidemeyer and Nikhil Yawalkar \\ Department of Dermatology, Inselspital, Bern University Hospital, University of Bern, Bern 3010, Switzerland; \\ Kristine.Heidemeyer@insel.ch (K.H.); Nikhil.Yawalkar@insel.ch (N.Y.) \\ * Correspondence: laurence.feldmeyer@insel.ch; Tel.: +41-31-632-6622; Fax: +41-31-632-2231 \\ Academic Editor: Chris Jackson \\ Received: 25 April 2016; Accepted: 13 July 2016; Published: 27 July 2016
}

\begin{abstract}
Acute generalized exanthematous pustulosis (AGEP) is a severe, usually drug-related reaction, characterized by an acute onset of mainly small non-follicular pustules on an erythematous base and spontaneous resolution usually within two weeks. Systemic involvement occurs in about $20 \%$ of cases. The course is mostly benign, and only in rare cases complications lead to life-threatening situations. Recent studies highlight the importance of genetic variations in interleukin-36 receptor antagonist gene $(I L-36 R N)$ in the pathogenesis of this disease. The physiopathology of AGEP remains unclear, but an involvement of innate and acquired immune cells together with resident cells (keratinocytes), which recruit and activate neutrophils via production of cytokines/chemokines such as IL-17, IL-36, granulocyte-macrophage colony-stimulating factor (GM-CSF), tumor necrosis factor alpha (TNF $\alpha$ ) and chemokine (C-X-C motif) ligand 8 (CXCL8)/IL-8, has been postulated. Treatment is based on the removal of the causative drug, supportive care, infection prevention and use of potent topical or systemic steroids.
\end{abstract}

Keywords: acute generalized exanthematous pustulosis; dermatology; skin; drug reaction

\section{Introduction}

Cutaneous adverse reactions to drugs are common and encompass a variety of mild to severe and life-threatening reactions. Acute generalized exanthematous pustulosis (AGEP) represents a severe, usually drug-related skin reaction characterized by acute formation of sterile pustules on an erythematous background, fever and neutrophilia.

\section{Background and Epidemiology}

While the clinical picture of drug-induced pustular eruptions in patients without any history of psoriasis had already been described in 1968 by Baker and Ryan, the term AGEP was introduced by Beylot et al. in 1980 [1,2]. AGEP is a rare adverse drug reaction with an incidence of one to five cases per million per year [3], but it might be underreported. It can occur at any age and seems to be more frequent in women [4].

\section{Aetiology}

Although many causative factors leading to AGEP have been described, it is, in over $90 \%$ of cases, associated with the ingestion of drugs [5,6]. Aminopenicillins, pristinamycin, sulphonamides, quinolones, hydroxychloroquine, terbinafin and diltiazem are the most frequent causative drugs [7]. In particular cases, AGEP is induced by bacterial, viral or parasitic infections (e.g., parvovirus B19 [8,9], mycoplasma [10,11], cytomegalovirus [12], coxsackie B4 [13], Chlamydia pneumoniae [14], 
Escherichia coli [15], and echinococcus [16]), spider bites [17], herbal medications [18], lacquer [18], mercury [19] and even psoralen combined with ultraviolet A (PUVA) treatment [20]. Finally venoms, foods and xenobiotics have also been suspected to induce the reaction [21].

\section{Genetic Background}

The genetic predisposition for the development of AGEP is not known. There seems to be a correlation between mutations in the $I L-36 R N$ gene, encoding the interleukine-36 receptor antagonist (IL-36Ra), and the development of generalized pustular eruptions after drug intake. IL-36Ra has an anti-inflammatory function and blocks the proinflammatory cytokines IL-36 $\alpha$, IL-36 $\beta$ and IL-36 $\gamma$. Mutations in the IL-36RN gene can result in uncontrolled IL-36 signalling and increased downstream production of further proinflammatory cytokines and chemokines [22]. However, it is still unclear if mutations in IL-36RN lead to AGEP or, rather, to a drug-induced generalized pustular psoriasis (GPP), as it is described in some cases $[23,24]$.

\section{Pathogenesis}

AGEP has been classified as a T cell-related sterile neutrophilic inflammatory response (type IVd reaction) [25-27]. The activation, proliferation and migration of drug-specific cluster of differentiation (CD) 4 and CD8 T cells play an important role in the development of AGEP (Figure 1), as supported by the use of patch tests [17-20] and in vitro tests [21,22]. It is supposed that drug-specific cytotoxic T cells and cytotoxic proteins such as granzyme B and perforin induce the apoptosis of keratinocytes, leading to subcorneal vesicles $[27,28]$. Recently, it has also been shown that, besides in toxic epidermal necrolysis (TEN), granulysin is also expressed by CD4 and CD8 T cells and natural killer (NK) cells in different drug reactions including AGEP, suggesting that granulysin may also play a role in the pathogenesis of AGEP [28]. Furthermore, in vitro tests have shown that drug-specific $T$ cells in AGEP patients produced significantly more chemokine (C-X-C motif) ligand 8 (CXCL8)/IL-8, a potent neutrophil chemotactic chemokine [26-29]. CXCL8/IL-8 is thought to play a central role in the formation of pustules by recruitment of neutrophils. The increased levels of IL-17 and IL-22 as well as granulocyte-macrophage colony-stimulating factor (GM-CSF) in AGEP patients may also participate in the strong neutrophilic activity by the synergistic effect on the production of CXCL8/IL-8 and the prevention of apoptosis of the neutrophils [28,29]. Recent studies also described a higher level of IL-17 expression by neutrophils, mast cells (MC), and macrophages, and a lower level by T cells, in AGEP patients, indicating that innate cells may also be involved in the pathogenesis of AGEP [29]. Furthermore, a deficiency in the IL36-Ra in some AGEP patients seems to play a role, leading to the increased expression of various proinflammatory cytokines and chemokines such as IL-1, IL-6, IL-12, IL-23, IL-17, tumor necrosis factor alpha (TNF $\alpha$ ) and CXCL8/IL-8, which can further enhance neutrophilic recruitment and activation $[22,23,30]$.

A. Activation and expansion of drug-specific T cells
B. Migration to the skin

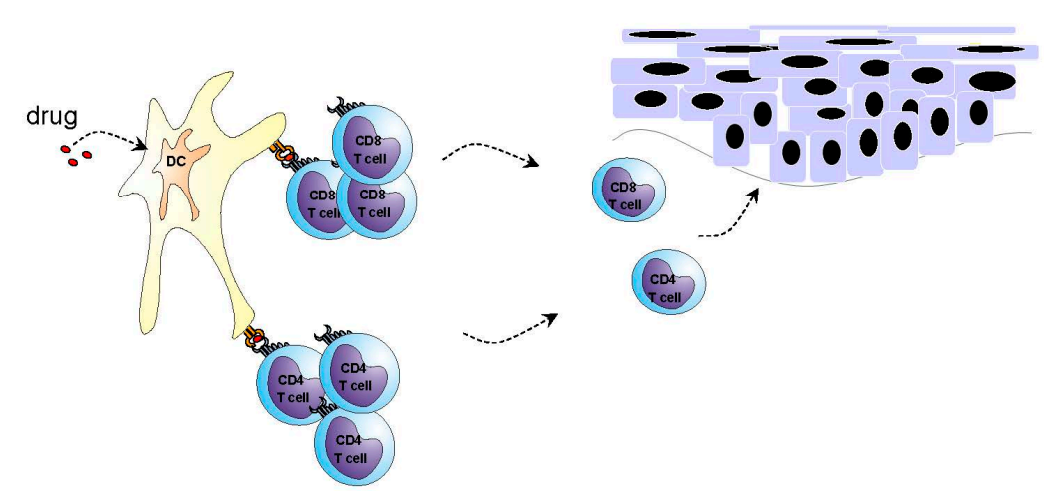

Figure 1. Cont. 


\section{Apoptosis of keratinocytes and formation of subcorneal vesicle}

- Granzyme B

- Granulysin

FAS-FASL

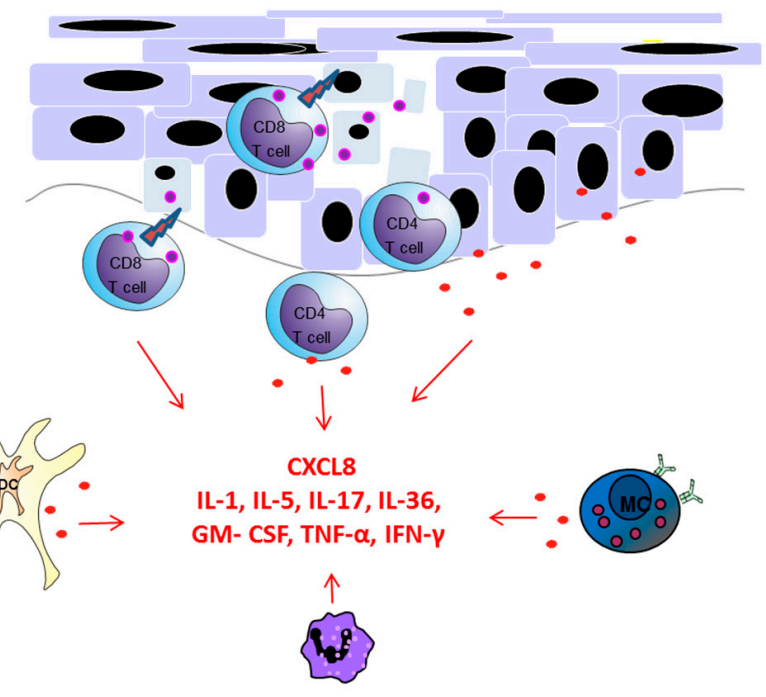

D. Release of various cytokines and chemokines ( () by innate and acquired immune cells and resident cells (i.e.keratinocytes)

E. Recruitment of further leucocytes, i.e. neutrophils and formation of pustules

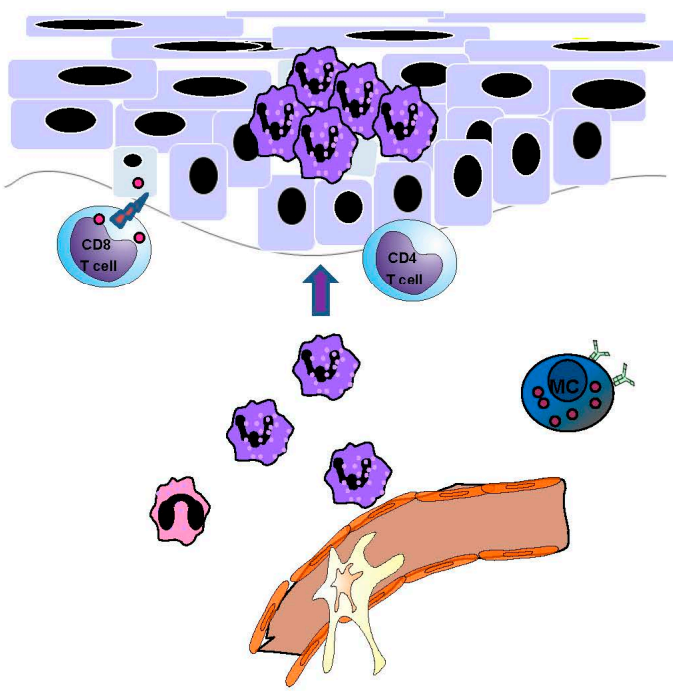

Figure 1. Putative pathogenic mechanisms in acute generalized exanthematous pustulosis (AGEP). (A) In cases with drug involvement, the initial phase involves stimulation of drug-specific T cells and (B) their migration to the skin; (C) These T cells, possibly together with natural killer T (NKT) cells/natural killer (NK) cells are activated in the skin, where they induce apoptosis of keratinocytes through cytotoxic proteins and Fas/Fas ligand (FasL) interactions resulting in the formation of subcorneal vesicles; (D) Furthermore, these T cells together with subsequently activated bystander and inflammatory cells (keratinocytes, dendritic cells (DC), MC, neutrophils) release various cytokines and chemokines; (E) which predominately lead to neutrophilic inflammation and the formation of pustules.

In some AGEP patients, IL-5 expressed by infiltrating $\mathrm{T}$ cells may lead to the eosinophilia presented in about $30 \%$ of AGEP patients [26]. An elevated expression of TNF $\alpha$ in AGEP patients has been reported [31]. 


\section{Clinical Features and Variants}

Characteristically, patients with AGEP develop an acute rash with pinhead-sized pustules on an erythematous oedematous base, starting in the main folds (axillary, inguinal and submammary areas) and spreading quickly (within a few hours) on the trunk and limbs (Figure 2). The time period from drug ingestion to reaction onset is usually within $48 \mathrm{~h}$, with antibiotics having a median of $24 \mathrm{~h}$ [7]. There is an itching or sometimes burning sensation [3,32]. Mucosal involvement, especially orally, is reported in about $20 \%-25 \%$ of patients but mostly in a limited extension and only on one mucosal region [5].

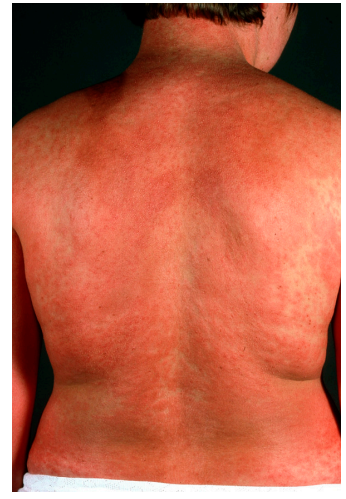

A

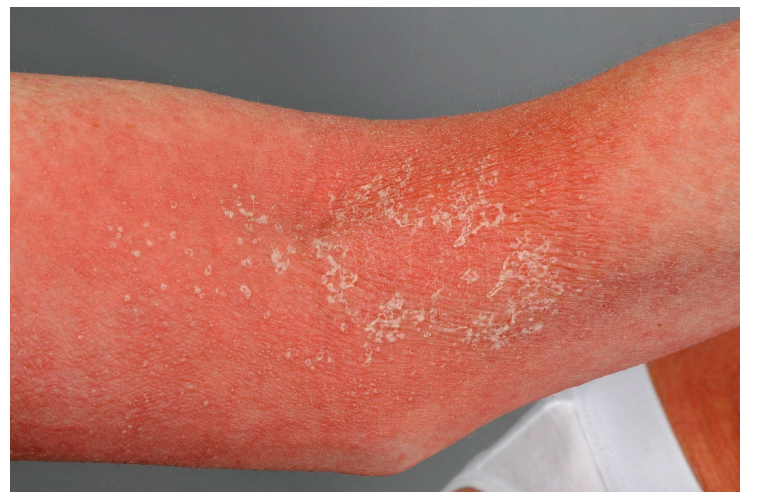

B

Figure 2. (A) Widespread rash with numerous pinhead-sized pustules on an erythematous oedematous base; (B) Flexural accentuation with characteristic collarette-shaped desquamation is typically observed in AGEP.

Systemic inflammation signs in the acute phase of the disease include fever $\left(>38.0^{\circ} \mathrm{C}\right)$, leucocytosis $(>10,000 / \mathrm{mL})$, elevated levels of C-reactive protein (CRP) and mostly increased levels of neutrophils $(>7000 / \mathrm{mL})$. As mentioned above, $30 \%$ of patients also present an eosinophilia and in $75 \%$ of cases a hypocalcaemia, probably related to hypoalbuminemia, is found [5,33]. Multiorgan involvement has been reported in $17 \%$ of cases [33]. Skin eruptions are sometimes accompanied by lymphadenopathy and occasionally by hepatocellular dysfunction and cholestasis as well as nephritis. Lung and bone marrow might also be involved, leading to respiratory failure and neutropenia, respectively [33]. One case with phenytoin-induced AGEP and cerebellar symptoms has been reported, while it is unknown whether cerebellar symptoms were related to the drug reaction or to phenytoin toxicity [34]. AGEP usually shows a mild course but high fever or cutaneous superinfection can complicate the process and lead to severe illness and sometimes life-threatening situations, especially in patients of poor general condition. The reported mortality is under 5\% [3,4]. Usually there is a spontaneous resolution of skin lesions within two weeks with a very typical collarette-shaped desquamation in the region of previous pustulosis [3,4].

Besides the normal presentation of AGEP, several atypical variants and overlap syndromes have been described. For example, an overlap of AGEP and drug reaction with eosinophilia and systemic symptoms (DRESS) [35,36], or TEN [36-44], as well as an AGEP case with targetoid lesions [45,46] have been reported. A dozen of localized reactions have been reported, and referred to as acute localized exanthematous pustulosis (ALEP) [47-50]. In about 50\% of patients, additional skin symptoms such as erythematous oedema of the hand and face, purpura, vesicles and blisters have been reported.

Differential diagnosis of other pustular eruptions (such as bacterial or fungal infections, neutrophilic dermatoses, etc.) can mostly be excluded easily by clinical picture, history and histopathological findings. Acute GPP can present with the same clinical picture and may be difficult to distinguish, as the histopathological findings can sometimes not clearly distinguish between these two diseases (Table 1). The most important factor for the diagnosis is the quicker resolution time seen in AGEP. Recent studies described similarities in the pathogenesis of AGEP and GPP, like mutations in 
the IL-36Ra and an elevated expression of IL-17 [51]. DRESS typically presents with a morbilliform rash spreading from the face to the rest of the body, but might present with pustules as well. DRESS develops with a longer latent period of two to six weeks and mucous membranes and systemic involvement are more common [52]. Stevens-Johnson syndrome (SJS) and TEN are characterized by epidermal detachment and histological full-thickness epidermal necrosis [53]. Severe cases of AGEP, especially those with mucosal involvement, might be difficult to distinguish from these entities, and overlap forms have been described.

Table 1. Factors favoring the diagnosis of AGEP over pustular psoriasis.

\begin{tabular}{lll}
\hline & AGEP & Generalized Pustular Psoriasis \\
\hline $\begin{array}{l}\text { History of psoriasis } \\
\text { (family/personal) }\end{array}$ & usually lacking & often present \\
\hline Distribution pattern & initially predominance in the folds & more generalized \\
\hline Onset of pustules & fast (hours or few days after use of medication) & slower \\
\hline Duration of pustules & $\begin{array}{l}\text { Shorter (rapid resolution in a few days, max. 15 days, } \\
\text { after drug suspension) }\end{array}$ & longer \\
\hline Size of pustules & tiny (pinhead) & larger \\
\hline Duration of eruption/fever & shorter (resolution in a few days after drug suspension) & longer \\
\hline History of drug reaction & usual & uncommon \\
\hline Recent drug administration & very frequent & less frequent \\
\hline Arthritis & rare & \begin{tabular}{l} 
about 30\% \\
\hline Histology
\end{tabular} \\
\hline
\end{tabular}

\section{Histopathological Findings}

A histopathological examination should be performed to distinguish AGEP from other pustular eruptions. The skin biopsy should include a pustule. Typically, the biopsy shows spongiform subcorneal and/or intraepithelial pustules, an oedematous papillary dermis and perivascular infiltrates with neutrophils and some eosinophils (Figure 3). In some cases, necrotic keratinocytes and leucocytoclastic vasculitis can also be found. Histopathologically, it can be difficult to differentiate AGEP from GPP. The presence of eosinophils, necrotic keratinocytes, a mixed interstitial and mid-dermal perivascular infiltrate and absence of tortuous or dilated blood vessels favors AGEP, while the presence of psoriasiform acanthosis is characteristic of GPP [24,54].

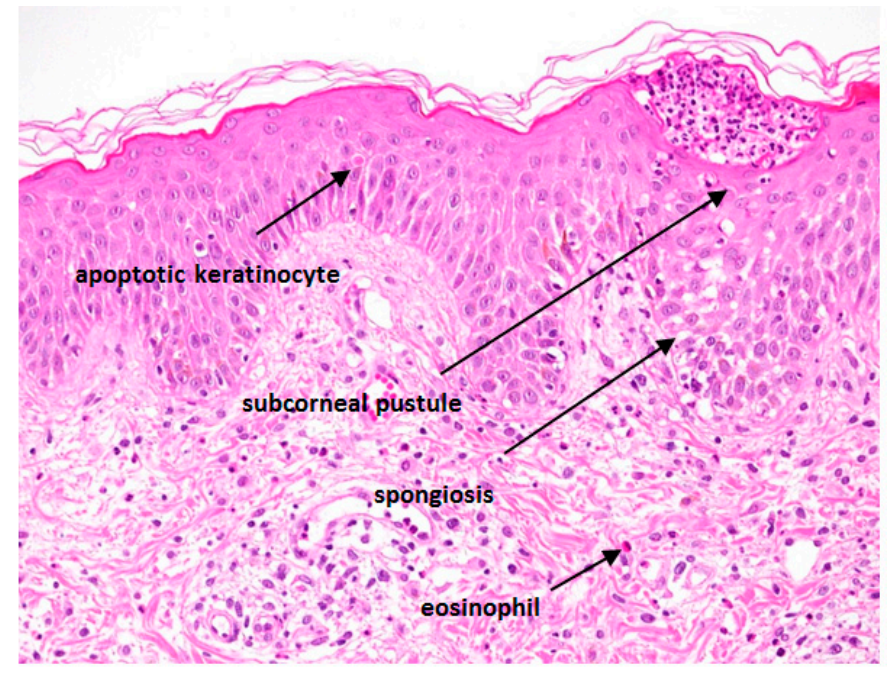

Figure 3. Typical histological features of AGEP are indicated. 


\section{Diagnosis}

Diagnosis of AGEP can be made clinically with the support of histopathological findings as well as patch tests. The EuroSCAR study group presented a standardized scoring system in 2001, the AGEP validation score, including the morphology of skin lesions, the presence of fever, the clinical course, and the laboratory and histopathological findings [4]. To identify the responsible drug in case of polymedication, a patch test can be performed after complete skin resolution. The sensibility of the patch test in AGEP is higher than in other drug reactions such as SJS or TEN (58\% positive in AGEP vs. $24 \%$ positive in SJS/TEN). A positive result often shows small pustules at the location of testing [55-57].

\section{Therapy}

Discontinuation of the causative agent is the main objective. Due to the mostly benign and self-limiting course, a supportive treatment based on topical steroids and disinfectant solutions during the pustular phase and rehydrating lotions during the desquamative phase, as well as antipyretics, is usually sufficient. In very extensive rashes, the intake of systemic steroids for a short time can be discussed [4], although there is no evidence that they reduce disease duration: their use is empirical and not supported by any randomized study. In one report, there was no difference between different treatment regimens regarding the course and duration of the disease or the length of fever $[6,18,58]$. Two cases of steroid-induced AGEP have been reported [58].

\section{Conclusions}

Recent research has improved our understanding of the pathophysiology of the disease but so far no markers have been identified that can predict which patients will develop the disease. The establishment of precise diagnostic criteria in AGEP is definitely a fundamental basis for clinical trials of quality [4]. There are currently no published randomized trials for a topical or systemic therapy for AGEP. Such trials are difficult to perform in a rare disease but necessary to provide a definitive answer. It is important to sensitize dermatologists and internists to this diagnosis as we feel that this disease is underreported. Indeed, the rash is usually not life-threatening and has a high rate of spontaneous resolution, so patients are not always referred to a dermatologist.

Acknowledgments: This work was supported by a Swiss Cancer Research Foundation grant (BIL KFS-3344-02-2014) to L.F. No funding was received for covering the costs to publish in open access.

Conflicts of Interest: The authors declare no conflict of interest.

\section{References}

1. Beylot, C.; Bioulac, P.; Doutre, M.S. Acute generalized exanthematic pustuloses (four cases). Ann. Dermatol. Vénéréol. 1980, 107, 37-48. [PubMed]

2. Baker, H.; Ryan, T.J. Generalized pustular psoriasis. A clinical and epidemiological study of 104 cases. Br. J. Dermatol. 1968, 80, 771-793. [CrossRef] [PubMed]

3. Sidoroff, A. Acute generalized exanthematous pustulosis. Chem. Immunol. Allergy 2012, 97, 139-148. [PubMed]

4. Sidoroff, A.; Halevy, S.; Bavinck, J.N.; Vaillant, L.; Roujeau, J.C. Acute generalized exanthematous pustulosis (AGEP)-A clinical reaction pattern. J. Cutan. Pathol. 2001, 28, 113-119. [CrossRef] [PubMed]

5. Roujeau, J.C.; Bioulac-Sage, P.; Bourseau, C.; Guillaume, J.C.; Bernard, P.; Lok, C.; Plantin, P.; Claudy, A.; Delavierre, C.; Vaillant, L. Acute generalized exanthematous pustulosis. Analysis of 63 cases. Arch. Dermatol. 1991, 127, 1333-1338. [CrossRef] [PubMed]

6. Chang, S.-L.; Huang, Y.-H.; Yang, C.-H.; Hu, S.; Hong, H.-S. Clinical manifestations and characteristics of patients with acute generalized exanthematous pustulosis in Asia. Acta Derm. Venereol. 2008, 88, 363-365. [PubMed] 
7. Sidoroff, A.; Dunant, A.; Viboud, C.; Halevy, S.; Bavinck, J.N.B.; Naldi, L.; Mockenhaupt, M.; Fagot, J.-P.; Roujeau, J.-C. Risk factors for acute generalized exanthematous pustulosis (AGEP)-results of a multinational case-control study (EuroSCAR). Br. J. Dermatol. 2007, 157, 989-996. [CrossRef] [PubMed]

8. Ofuji, S.; Yamamoto, O. Acute generalized exanthematous pustulosis associated with a human parvovirus B19 infection. J. Dermatol. 2007, 34, 121-123. [CrossRef] [PubMed]

9. Lee, D.; Kang, J.N.; Hwang, S.H.; Lee, Y.S.; Kim, H.; Seo, J.K.; Sung, H.S. Acute generalized exanthematous pustulosis induced by parvovirus b19 infection. Ann. Dermatol. 2014, 26, 399-400. [CrossRef] [PubMed]

10. Lim, C.S.-H.; Lim, S.-L. Acute generalized exanthematous pustulosis associated with asymptomatic Mycoplasma pneumoniae infection. Arch. Dermatol. 2009, 145, 848-849. [CrossRef] [PubMed]

11. Taguchi, K.; Oka, M.; Bito, T.; Nishigori, C. Acute generalized exanthematous pustulosis induced by Mycoplasma pneumoniae infection. J. Dermatol. 2016, 43, 113-114. [CrossRef] [PubMed]

12. Haro-Gabaldón, V.; Sánchez-Sánchez-Vizcaino, J.; Ruiz-Avila, P.; Gutiérrez-Fernández, J.; Linares, J.; Naranjo-Sintes, R. Acute generalized exanthematous pustulosis with cytomegalovirus infection. Int. J. Dermatol. 1996, 35, 735-737. [CrossRef] [PubMed]

13. Feio, A.B.; Apetato, M.; Costa, M.M.; Sá, J.; Alcantara, J. Acute generalized exanthematous pustulosis due to Coxsackie B4 virus. Acta Méd. Port. 1997, 10, 487-491. [PubMed]

14. Manzano, S.; Guggisberg, D.; Hammann, C.; Laubscher, B. Acute generalized exanthematous pustulosis: First case associated with a Chlamydia pneumoniae infection. Arch. Pédiatrie Organe Off. Soc. Fr. Pédiatrie 2006, 13, 1230-1232. [CrossRef] [PubMed]

15. Klein, N.; Hartmann, M.; Helmbold, P.; Enk, A. Acute generalized exanthematous pustulosis associated with recurrent urinary tract infections. Hautarzt Z. Für Dermatol. Venerol. Verwandte Geb. 2009, 60, $226-228$. [CrossRef] [PubMed]

16. Cannistraci, C.; Parola, I.L.L.A.; RiganO, R.; Bassetti, F.; Ortona, E.; Santucci, B.; Picardo, M.; Siracusano, S. Acute generalized exanthematous pustulosis in cystic echinococcosis: Immunological characterization. Br. J. Dermatol. 2003, 148, 1245-1249. [CrossRef] [PubMed]

17. Davidovici, B.B.; Pavel, D.; Cagnano, E.; Rozenman, D.; Halevy, S.; EuroSCAR; RegiSCAR study group. Acute generalized exanthematous pustulosis following a spider bite: Report of 3 cases. J. Am. Acad. Dermatol. 2006, 55, 525-529. [CrossRef] [PubMed]

18. Choi, M.J.; Kim, H.S.; Park, H.J.; Park, C.J.; Lee, J.D.; Lee, J.Y.; Kim, H.O.; Park, Y.M. Clinicopathologic manifestations of 36 Korean patients with acute generalized exanthematous pustulosis: A case series and review of the literature. Ann. Dermatol. 2010, 22, 163-169. [CrossRef] [PubMed]

19. Belhadjali, H.; Mandhouj, S.; Moussa, A.; Njim, L.; Amri, M.; Zakhama, A.; Zili, J. Mercury-induced acute generalized exanthematous pustulosis misdiagnosed as a drug-related case. Contact Dermat. 2008, 59, 52-54. [CrossRef] [PubMed]

20. Bonnetblanc, J.M.; Combeau, A.; Dang, P.M. Hydroxychloroquine-puvatherapy photoinduced acute generalized exanthematous pustulosis. Ann. Dermatol. Vénéréol. 1995, 122, 604-605. [PubMed]

21. Raison-Peyron, N. “Cutaneous adverse drug reactions" are not always drug-induced. Eur. J. Dermatol. 2013, 23, 439-442. [PubMed]

22. Gabay, C.; Towne, J.E. Regulation and function of interleukin-36 cytokines in homeostasis and pathological conditions. J. Leukoc. Biol. 2015, 97, 645-652. [CrossRef] [PubMed]

23. Navarini, A.A.; Valeyrie-Allanore, L.; Setta-Kaffetzi, N.; Barker, J.N.; Capon, F.; Creamer, D.; Roujeau, J.C.; Sekula, P.; Simpson, M.A.; Trembath, R.C.; et al. Rare variations in IL36RN in severe adverse drug reactions manifesting as acute generalized exanthematous pustulosis. J. Investig. Dermatol. 2013, 133, 1904-1907. [CrossRef] [PubMed]

24. Halevy, S.; Kardaun, S.H.; Davidovici, B.; Wechsler, J.; EuroSCAR; RegiSCAR study group. The spectrum of histopathological features in acute generalized exanthematous pustulosis: A study of 102 cases. Br. J. Dermatol. 2010, 163, 1245-1252. [CrossRef] [PubMed]

25. Britschgi, M.; Pichler, W.J. Acute generalized exanthematous pustulosis, a clue to neutrophil-mediated inflammatory processes orchestrated by T cells. Curr. Opin. Allergy Clin. Immunol. 2002, 2, 325-331. [CrossRef] [PubMed]

26. Britschgi, M.; Steiner, U.C.; Schmid, S.; Depta, J.P.; Senti, G.; Bircher, A.; Burkhart, C.; Yawalkar, N.; Pichler, W.J. T-cell involvement in drug-induced acute generalized exanthematous pustulosis. J. Clin. Investig. 2001, 107, 1433-1441. [CrossRef] [PubMed] 
27. Schmid, S.; Kuechler, P.C.; Britschgi, M.; Steiner, U.C.; Yawalkar, N.; Limat, A.; Baltensperger, K.; Braathen, L.; Pichler, W.J. Acute generalized exanthematous pustulosis: Role of cytotoxic T cells in pustule formation. Am. J. Pathol. 2002, 161, 2079-2086. [CrossRef]

28. Schlapbach, C.; Zawodniak, A.; Irla, N.; Adam, J.; Hunger, R.E.; Yerly, D.; Pichler, W.J.; Yawalkar, N. NKp46+ cells express granulysin in multiple cutaneous adverse drug reactions. Allergy 2011, 66, 1469-1476. [CrossRef] [PubMed]

29. Kabashima, R.; Sugita, K.; Sawada, Y.; Hino, R.; Nakamura, M.; Tokura, Y. Increased circulating Th17 frequencies and serum IL-22 levels in patients with acute generalized exanthematous pustulosis. J. Eur. Acad. Dermatol. Venereol. 2011, 25, 485-488. [CrossRef] [PubMed]

30. Marrakchi, S.; Guigue, P.; Renshaw, B.R.; Puel, A.; Pei, X.Y.; Fraitag, S.; Zribi, J.; Bal, E.; Cluzeau, C.; Chrabieh, M.; et al. Interleukin-36-receptor antagonist deficiency and generalized pustular psoriasis. N. Engl. J. Med. 2011, 365, 620-628. [CrossRef] [PubMed]

31. Meiss, F.; Helmbold, P.; Meykadeh, N.; Gaber, G.; Marsch, W.C.; Fischer, M. Overlap of acute generalized exanthematous pustulosis and toxic epidermal necrolysis: Response to antitumour necrosis factor-alpha antibody infliximab: Report of three cases. J. Eur. Acad. Dermatol. Venereol. 2007, 21, 717-719. [CrossRef] [PubMed]

32. Beylot, C.; Doutre, M.S.; Beylot-Barry, M. Acute generalized exanthematous pustulosis. Semin. Cutan. Med. Surg. 1996, 15, 244-249. [CrossRef]

33. Hotz, C.; Valeyrie-Allanore, L.; Haddad, C.; Bouvresse, S.; Ortonne, N.; Duong, T.A.; Ingen-Housz-Oro, S.; Roujeau, J.C.; Wolkenstein, P.; Chosidow, O. Systemic involvement of acute generalized exanthematous pustulosis: A retrospective study on 58 patients. Br. J. Dermatol. 2013, 169, 1223-1232. [CrossRef] [PubMed]

34. Shingade, P.U.; Wankhede, V.; Kataria, P.S.; Sonone, N. Rare case of phenytoin induced acute generalized exanthematous pustulosis with cerebellar syndrome. Indian J. Dermatol. 2014, 59, 210. [CrossRef] [PubMed]

35. Gey, A.; Milpied, B.; Dutriaux, C.; Mateus, C.; Robert, C.; Perro, G.; Taieb, A.; Ezzedine, K.; Jouary, T. Severe cutaneous adverse reaction associated with vemurafenib: DRESS, AGEP or overlap reaction? J. Eur. Acad. Dermatol. Venereol. 2016, 30, 178-179. [CrossRef] [PubMed]

36. Bouvresse, S.; Valeyrie-Allanore, L.; Ortonne, N.; Konstantinou, M.P.; Kardaun, S.H.; Bagot, M.; Wolkenstein, P.; Roujeau, J.C. Toxic epidermal necrolysis, DRESS, AGEP: Do overlap cases exist? Orphanet J. Rare Dis. 2012. [CrossRef] [PubMed]

37. Cohen, A.D.; Cagnano, E.; Halevy, S. Acute generalized exanthematous pustulosis mimicking toxic epidermal necrolysis. Int. J. Dermatol. 2001, 40, 458-461. [CrossRef] [PubMed]

38. Scheinfeld, N.; Wesson, K.; Perry, P.; Weinberg, J. Acute generalized exanthematous pustulosis resembling toxic epidermal necrolysis caused by famotidine. Acta Derm. Venereol. 2003, 83, 76-77. [PubMed]

39. Peermohamed, S.; Haber, R.M. Acute generalized exanthematous pustulosis simulating toxic epidermal necrolysis: A case report and review of the literature. Arch. Dermatol. 2011, 147, 697-701. [CrossRef] [PubMed]

40. Goh, T.K.; Pang, S.M.; Thirumoorthy, T.; Goh, S.G.N. Acute generalised exanthematous pustulosis and toxic epidermal necrolysis induced by carbamazepine. Singap. Med. J. 2008, 49, 507-510.

41. Lateef, A.; Tan, K.B.; Lau, T.C. Acute generalized exanthematous pustulosis and toxic epidermal necrolysis induced by hydroxychloroquine. Clin. Rheumatol. 2009, 28, 1449-1452. [CrossRef] [PubMed]

42. Worsnop, F.; Chong, H.; Ostlere, L.; Natkunarajah, J. Acute generalized exanthematous pustulosis mimicking toxic epidermal necrolysis in patients with psoriasis: A coincidence? Clin. Exp. Dermatol. 2015, 40, 688-689. [CrossRef] [PubMed]

43. Smith, V.M.; Pollock, B.; Wilkinson, S.M.; Rose, R.F. Acute generalized exanthematous pustulosis mimicking toxic epidermal necrolysis in patients with psoriasis. Clin. Exp. Dermatol. 2016, 40, 688-689. [CrossRef] [PubMed]

44. Moling, O.; Perino, F.; Piccin, A. Acute generalized exanthematous pustulosis with overlap features of toxic epidermal necrolysis/Stevens-Johnson syndrome. Int. J. Dermatol. 2014, 53, e27-e28. [CrossRef] [PubMed]

45. Lin, J.H.; Sheu, H.M.; Lee, J.Y.-Y. Acute generalized exanthematous pustulosis with erythema multiforme-like lesions. Eur. J. Dermatol. 2002, 12, 475-478. [PubMed]

46. Poeschl, M.D.; Hurley, M.Y.; Goyal, S.D.; Vidal, C.I. Targetoid eruptions: Acute generalized exanthematous pustulosis. Am. J. Dermatopathol. 2014, 36, 827-828. [CrossRef] [PubMed] 
47. Corral de la Calle, M.; Martín Díaz, M.A.; Flores, C.R.; Vidaurrazaga, C. Acute localized exanthematous pustulosis secondary to levofloxacin. Br. J. Dermatol. 2005, 152, 1076-1077. [CrossRef] [PubMed]

48. Kim, S.W.; Lee, U.H.; Jang, S.J.; Park, H.S.; Kang, Y.S. Acute localized exanthematous pustulosis induced by docetaxel. J. Am. Acad. Dermatol. 2010, 63, e44-e46. [CrossRef] [PubMed]

49. Liang, C.P.; Yang, C.S.; Shen, J.L.; Chen, Y.J. Sorafenib-induced acute localized exanthematous pustulosis in a patient with hepatocellular carcinoma. Br. J. Dermatol. 2011, 165, 443-445. [CrossRef] [PubMed]

50. Tresch, S.; Cozzio, A.; Kamarashev, J.; Harr, T.; Schmid-Grendelmeier, P.; French, L.E.; Feldmeyer, L. T cell-mediated acute localized exanthematous pustulosis caused by finasteride. J. Allergy Clin. Immunol. 2012, 129, 589-594. [CrossRef] [PubMed]

51. Kakeda, M.; Schlapbach, C.; Danelon, G.; Tang, M.M.; Cecchinato, V.; Yawalkar, N.; Uguccioni, M. Innate immune cells express IL-17A/F in acute generalized exanthematous pustulosis and generalized pustular psoriasis. Arch. Dermatol. Res. 2014, 306, 933-938. [CrossRef] [PubMed]

52. Husain, Z.; Reddy, B.Y.; Schwartz, R.A. DRESS syndrome: Part I. Clinical perspectives. J. Am. Acad. Dermatol. 2013, 68, 693.e1-693.e14. [CrossRef] [PubMed]

53. Schwartz, R.A.; McDonough, P.H.; Lee, B.W. Toxic epidermal necrolysis: Part I. Introduction, history, classification, clinical features, systemic manifestations, etiology, and immunopathogenesis. J. Am. Acad. Dermatol. 2013, 69, 173.e1-173.e13. [CrossRef] [PubMed]

54. Kardaun, S.H.; Kuiper, H.; Fidler, V.; Jonkman, M.F. The histopathological spectrum of acute generalized exanthematous pustulosis (AGEP) and its differentiation from generalized pustular psoriasis. J. Cutan. Pathol. 2010, 37, 1220-1229. [CrossRef] [PubMed]

55. Wolkenstein, P.; Chosidow, O.; Fléchet, M.L.; Robbiola, O.; Paul, M.; Dumé, L.; Revuz, J.; Roujeau, J.C. Patch testing in severe cutaneous adverse drug reactions, including Stevens-Johnson syndrome and toxic epidermal necrolysis. Contact Dermat. 1996, 35, 234-236. [CrossRef]

56. Barbaud, A. Drug patch testing in systemic cutaneous drug allergy. Toxicology 2005, 209, 209-216. [CrossRef] [PubMed]

57. Barbaud, A.; Collet, E.; Milpied, B.; Assier, H.; Staumont, D.; Avenel-Audran, M.; Grange, A.; Amarger, S.; Girardin, P.; Guinnepain, M.-T.; et al. A multicentre study to determine the value and safety of drug patch tests for the three main classes of severe cutaneous adverse drug reactions. Br. J. Dermatol. 2013, 168, 555-562. [CrossRef] [PubMed]

58. Buettiker, U.; Keller, M.; Pichler, W.J.; Braathen, L.R.; Yawalkar, N. Oral prednisolone induced acute generalized exanthematous pustulosis due to corticosteroids of group A confirmed by epicutaneous testing and lymphocyte transformation tests. Dermatology 2006, 213, 40-43. [CrossRef] [PubMed]

(C) 2016 by the authors; licensee MDPI, Basel, Switzerland. This article is an open access article distributed under the terms and conditions of the Creative Commons Attribution (CC-BY) license (http:/ / creativecommons.org/licenses/by/4.0/). 